\title{
Histological, histochemical and immunohistochemical study on the growing oocytes of the abyssal teleost Hoplostethus mediterraneus (V)
}

\author{
Concetta Calabro, Maria Pia Albanese, Clara Bertuccio, Aurelio Licata, \\ Nunzia Gentile
}

Department of Animal Biology and Marine Ecology, Faculty of Science University of Messina, Italy.

\begin{abstract}
The oocytes of the abyssal Teleost, Hoplostethus mediterraneus were studied. Four stages of growth were observed and the oocytes of all the stages were surrounded by follicular cells and had several nucleoli in the nucleus. In the oocytes of the $\mathrm{II}^{\circ}$ stage, vacuoles without contents, in oocytes of the $\mathrm{III}^{\circ}$ stage several vacuoles with a basophilic contents and small yolk globules were identified. General and basic proteins, ribonucleoproteins, acid proteoglycans with -COOH groups were recognized in the cytoplasm, in the nucleoli of oocytes in the $\mathrm{II}^{\circ}$ stage and in the vacuolar contents of oocytes in the $\mathrm{III}^{\circ}$ stage. In the follicular cells, in the pellucid zone, in the yolk globules, from their beginning, glycoproteins were present. Positivity, for all lectins used, was revealed in the follicular cells and in the four stages of oocytes growth. $\alpha$-D-glucose and $\alpha$-D-mannose binding sites were in the pellucid zone and in the initial yolk globules. In the lather galactose and $\beta$-N-acetyl glucosamine were present too. nNOS and VIP immunopositivity revealed at the periphery of the cytoplasm and at network of nerve fibres between oocytes, suggests NO is involved in a mechanism of regulation of the gametogenesis and of the spawning.
\end{abstract}

Key words: Vitellogenesis - Teleost - Hoplostethus mediterraneus - Oocytes - Glycoconjugates - nNOS - VIP - Nerve fibres

\section{Introduction}

In the oocytes of a lot of Invertebrates and Vertebrates the different staining affinities among the initial, intermediate and definitive yolk globules were correlated with the variations in the chemical constitution of the nucleoli during vitellogenesis $[1,2]$.

Only in Mictophum punctatum the yolk globules had the same chemical constitution, though different staining affinities, [3].

The different GAG and endogen agglutinins (lectins) found in the cortical granules and in the jelly coat of the oocytes in some species of Teleostes $[4,5]$ were considered as substances preventing the polyspermia.

In the oocytes of different species of teleosts sugar specific sites were found in the follicular cells [6] as well as in the pellucid zone [7]. The phylogeny and functional roles of nNOS and VIP, present in different

Correspondence: M. P. Albanese, Dept. Animal Biology and Marine Ecology, University of Messina, Contrada Sperone,

198166 S. Agata, Messina, Italy;

e-mail: mariapia.albanese@unime.it tissues (epidermic, tegumental connective, musculature of swim-bladder, gills, lung) of Invertebrates and Vertebrates are still unclear. However recent studies indicate involvement of these bioactive compounds in the non adrenergic-non cholinergic (NANC) regulatory mechanism [8-10].

A recent immunohistochemical investigation on the mantle integument of the mussel Mytilus galloprovincialis [10], in order to detect, in both sexes, the presence of nNOS and VIP, resulted positive in cortex of sperm follicles and nNOS positive sperm only in the male, in the female positivity in the nerve cells bodies and fibres and negativity in the maturating oocytes.

The aim of this study was the investigation on the oocytes of abyssal teleost Hoplostethus mediterraneus in order to ascertain the presence of bioactive molecules too [9-13] and to confirm their role in the reproductive function.

\section{Materials and methods}

Specimen samples. Specimens of Hoplostethus mediterraneus caught in the Strait of Messina (Italy) were sacrificed and female gonads were isolated. They were fixed in Bouin and in $10 \%$ for- 
malin in sea water, for the morphological and structural study and in $4 \%$ paraformaldehyde buffered with $0.01 \mathrm{M}$ sodium phosphate (PBS), $\mathrm{pH}=7.4$ at $4^{\circ} \mathrm{C}$ for the histochemical and immunohistochemical study, then they were embedded in paraplast. Serial sections $(5 \mu \mathrm{m}$ tick) were stained with Mallory mod. Ignesti (Carazzi hemalum, $1 \%$ acid fuchsin, Mallory's solution) and Galgano I (Mayer's hemalum, $0.1 \%$ acidic fuchsin, 1\% phoshomolybdic acid, Mallory's solution).

Proteins. Following histochemical methods demonstrating proteins were used: bromophenol blue method, ninhydrin- Schiff, chloramines T-Schiff, performic acid-Schiff, Morel and Sisley, Millon, Adams reactions, diazoreaction and Sakaguchi reaction.

Glycoproteins. Following histochemical methods demonstrating proteins were used: PAS reaction according to Mc Manus, dimedone- PAS reaction. Acid proteoglycans $\mathrm{AB}(\mathrm{pH}=1.0)$; $\mathrm{AB}$ $(\mathrm{pH}=2.5)$. Distinction between glycoproteins and acidic proteoglycans; $\mathrm{AB} \mathrm{pH}=1.0-\mathrm{PAS} ; \mathrm{AB} \mathrm{pH}=2.5 \mathrm{PAS}$.

Distinction between acid proteoglycans with different acidities. $\mathrm{AB}$ - C.E.C. (critical electrolyte concentration): $0.05 \% \mathrm{AB}$, inhibition of alcianophilia at graded molarities of $0.5-1 \mathrm{M} \mathrm{MgCl}_{2}$ in acetic buffer $(\mathrm{pH}=5.8)$ weak methylation- $\mathrm{AB}(\mathrm{pH}=2.5)$; strong methylation- $\mathrm{AB}(\mathrm{pH}=2.5)$; weak methylation-saponification- $\mathrm{AB}$ $(\mathrm{pH}=2.5)$. Acid hydrolysis in $0.1 \mathrm{M}$ acetate buffer $(\mathrm{pH}=2.5)$ for $4 \mathrm{~h}$ at $60^{\circ} \mathrm{C}$ followed by $\mathrm{AB}(\mathrm{pH}=2.5)$, also without saponification.

Methods of enzymatic digestion. $\alpha$-amylase - PAS; AB-neuraminidase $(\mathrm{pH}=2.5)$, from Clostridium perfringens with and without saponification, testicular hyaluronidase [14] (Table 1).

Specific sugar residues. Biotinylated lectins and avidin-biotinperoxidase method $(\mathrm{ABC})$ was employed. The biotinylated lectins used (Vector Laboratories, Burningame, California, USA) their origin, specificity and inhibiting sugars are reported in Table 2. Incubating the sections with specific sugar performed controls.

Indirect immunoperoxidase method. Section of ovary were incubated overnight at $4^{\circ} \mathrm{C}$ in humid chamber with polyclonal rabbit anti-human brain nNOS antibody diluted 1:200 (nNOS type I Code 606-259-1550; Biomol, Hamburg, Germany) or polyclonal antihuman VIP antibodies (Biomeda, Foster City CA, USA). Afterwards, sections were washed in PBS and incubated for $2 \mathrm{~h}$ with a goat anti-rabbit IgG-peroxidase conjugate (1:100; Sigma, Munich, Germany). Peroxidase activity was visualized by incubation of the sections for 5-12 min at room temperature in a solution of $0.015 \%$ 3,3'-diaminobenzidine in $0.01 \mathrm{M}$ tris buffer $(\mathrm{pH}=7.6)$ containing $0.005 \% \mathrm{H}_{2} \mathrm{O}_{2}$. Negative controls included omission of the primary antibody or its substitution with non-immune rabbit serum.

NADPH diaphorase. To demonstrate NADH diaphorase activity, pieces of tissue were fixed for $2 \mathrm{~h}$ at room temp in a solution of $4 \%$ paraformaldehyde immediately after dissection. Afterwards, the pieces of tissue were incubated for $5 \mathrm{~min}$ in $0.1 \mathrm{M}$ PBS containing $0.25 \%$ Triton $\mathrm{X}-100$, and subsequently for $60 \mathrm{~min}$ at $37^{\circ} \mathrm{C}$ in a solution containing $3 \mathrm{mg} / \mathrm{ml}$ NADPH (Sigma, St Luis MO, USA) and $0.5 \mathrm{mM}$ nitroblue tetrazolium (Sigma). Then, the tissue were washed thoroughly, dehydrated and embedded in paraplast and sectioned ( $5 \mu \mathrm{m}$ thick). Control incubations were carried out using pieces of tissue incubated in media lacking NADPH.

\section{Results}

The structural examination on the ovarian isolated in the different months of a year from specimens of Hoplostethus mediterraneus, revealed four stages of
Table 1. Conventional histochemical methods for visualization and identification of glycoconjugates (GCs).

\begin{tabular}{|l|l|}
\hline \multicolumn{1}{|c|}{ Procedures } & \multicolumn{1}{c|}{ GCs revealed } \\
\hline PAS & Glycoproteins \\
\hline $\mathrm{AB} \mathrm{pH}=1.0$ & $\begin{array}{l}\text { Proteoglycans with sulphate } \\
\text { groups }\end{array}$ \\
\hline $\mathrm{AB} \mathrm{pH}=2.5$ & $\begin{array}{l}\text { Proteoglycans with carboxylic } \\
\text { groups }\end{array}$ \\
\hline $\mathrm{AB} \mathrm{pH}=2.5$ PAS & $\begin{array}{l}\text { Proteoglycans with carboxylic } \\
\text { groups and glycoproteins }\end{array}$ \\
\hline $\begin{array}{l}\text { Neuraminidase } \\
\text { enzymatic digestion }\end{array}$ & Sialic acid \\
\hline AB (C.E.C.) & Sialic acid \\
\hline
\end{tabular}

growth $[15,16]$. The oocytes in the $\mathrm{I}^{\circ}$ stage, about 20 000 of medium $\mu \mathrm{m}$ volume, had a homogeneous cytoplasm and were surrounded by a single layer of follicular cells. In nucleus there were up to six nucleoli, of which one was spherical and greater in size, the spherical others were smaller arranged along the nuclear membrane. By Mallory's modification Ignesti and Galgano I structural methods, the cytoplasm was strongly basophylic and the nucleoli were red stained (Fig. 1).

The oocytes in $\mathrm{II}^{\circ}$ stage, about $180000 \mu \mathrm{m}$ of medium volume, were larger and characterized by two layers of follicular cells arranged along the oocyte's membrane, in orders to form an epithelium at first monostratified and then pluristratified. Furthermore, they are characterized by the presence in the nucleus of a greater number of nucleoli, adhering to the membrane mainly scattered of round shape, with changing dimensions and strongly red stained with the above mentioned methods.

The oocytes in $\mathrm{III}^{\circ}$ stage, about $3000000 \mu \mathrm{m}$ of medium volume, were surrounded by several layers of follicular cells, of which, one thicker and thicker, with evident streaking, constituted the radiate or pellucid zone, strong red stained by Mallory.

In the cytoplasm of these oocytes there were also vacuoles with basophilic contents arranged in several layers (Fig. 2). In the cortical zone between the radiate zone and the vacuoles there were yolk globules extending from the periphery to the centre, at first they were red stained then turning from red into blue (Fig. 3 ). The nucleoli, of which one or two seemed more conspicuous, partly kept the red stain.

The oocytes of $\mathrm{IV}^{\circ}$ stage, about $20000000 \mu \mathrm{m}$ of medium volume, were surrounded by one layer of follicular cells, that in the most advanced vitellogenesis became shorter, cubic-shaped, surrounding the pellucid zone. In the oocyte's cytoplasm, the number of vacuoles decreased till to disappearing at the end of the vitellogenesis, at the same time, the yolk globules 
Table 2. Lectins employed and their major binding specificities.

\begin{tabular}{|c|c|c|c|}
\hline Lectin & Origin & Carbohydrate specificity & Inhibitory sugar \\
\hline ConA & Canavalia ensiformis & $\begin{array}{c}\alpha \text {-D-mannose } \\
\alpha \text {-D-glucose }\end{array}$ & D-Mann \\
\hline RCA & Ricinus communis & $\beta$-D-galactosyl & Lactose; D-galactose \\
\hline PNA & Arachis hypogaea & D-galactose & D-gal \\
\hline SBA & Glycine max & $\begin{array}{c}\text { N-acetyl-D- } \\
\text { Galactosamine }>\text { D-galactose }\end{array}$ \\
\hline UEA I & Ulex europaeus & $\alpha$-L-fucose & L-fucose \\
\hline WGA & Triticum vulgaris & $\begin{array}{c}\text { N-acetyl-D-galactosamine }> \\
\text { Sialic acid }\end{array}$ & D-GlcNAc \\
\hline
\end{tabular}

increased in number and in size gradually showing a blue stain. The nucleus became smaller in size. The nucleoli appeared red stained. The pellucid zone changed stain from red to blue (Fig. 3).

The basophilia in the cytoplasm of oocytes of $\mathrm{I}^{\circ}$ and $\mathrm{II}^{\circ}$ stages was confirmed by positivity for general and basic proteins (bromophenol blue with and without mercury dichloride methods). The pironinophilia in the cytoplasm is due to ribonucleoproteins. $\mathrm{AB}$ $\mathrm{pH}=1.0$ and $\mathrm{AB} \mathrm{pH}=2.5$ methods revealed the presence of acid proteoglycan with $-\mathrm{SH}$ and $-\mathrm{COOH}$ groups respectively. The negative result to PAS reaction sec. Mac Manus showed absence of glycoproteins. In the follicular cells, glycoproteins, (Fig. 4), acid proteoglycan with - $\mathrm{SH}$ and - $\mathrm{COOH}$ groups. In the nucleoli general and basic and ribonucleoproteins were present.

The contents of vacuoles, where present, was positive for general and basic proteins, glycoproteins (Fig. 4) without glycogen, acid proteoglycan with -SH and $\mathrm{COOH}$ groups coexisting with glycoproteins (Fig. 5). Follicular cells of oocytes of $\mathrm{I}^{\circ}$ and $\mathrm{II}^{\circ}$ stage and the $\mathrm{II}^{\circ}$ stage oocyte's cytoplasm were positive after use of the RCA, ConA, PNA, SBA, WGA, UEA I lectins. The follicular cells, the cytoplasm and vacuolar contents of oocytes $\mathrm{II}^{\circ}$ in advanced stage, were positive for $\alpha$-D-mannose and $\alpha$-D glucose (ConA) and for galactose (RCA) (Fig. 6).

The oocytes of III $^{\circ}$ stages showed a gradual decrease of basophilia, pironinophilia and positivity for the proteins. The latter substances were present in the yolk globules, in the nucleoli of oocytes and in the cytoplasm of the follicular cells. In the oocytes cytoplasm glycoproteins, without glycogen, acid proteoglycans with - $\mathrm{SH}$ and $-\mathrm{COOH}$ groups were present.

$\mathrm{AB}(\mathrm{pH}=1.0)$-PAS and $\mathrm{AB}(\mathrm{pH}=2.5)-\mathrm{PAS}$ reactions revealed glycoproteins and acid proteoglycans with $\mathrm{SH}$ and -COOH groups (Fig. 7) both in the cytoplasm and in the vacuolar contents. Only glycoproteins were present in the yolk globules, pellucid zone and follicular cells (Fig. 7). The acid proteoglycans were absent in the yolk globules, in the pellucid zone, in the nucleoli.

Use of all lectins always revealed positivity of binding sites for follicular cells. In most of the initial yolk globules the galactose (RCA) was present (Fig. 8). WGA revealed $\beta$-N-acetyl-glucosamine in the smaller yolk globules and in the follicular cells (Fig. 9).

In the oocytes of $\mathrm{IV}^{\circ}$ stage there was no correspondence between changes in stain and changes in the chemical constitution. In fact in the yolk globules there were proteins and glycoproteins. By using ConA and WGA (Fig. 10) positivity was shown only in the periphery. The use of the other lectins simply revealed negativity.

After immunohistochemistry analysis the cytoplasm of vitellogenic oocytes and of follicular cells was nNOS (Fig. 10) and VIP positive nerve fibres nNOS positive were found adjacent to maturating oocytes (Fig. 11).

Incubations in the absence of primary antibodies or their substitution by non-immune sera resulted in nerve fibres and follicular cells, were negative for nNOS and VIP. The final reaction product of NADPH diaphorase activity was present in nerve fibres and follicular cells. Distribution patterns of NADPH diaphorase were similar to the patterns of nNOS positive staining.

\section{Discussion}

The results obtained in Hoplostethus mediterraneus were revealed both analogies as well as differences to ward the other species studied, in particular with Coelorhinchus coelorhynchus abyssal teleost.

According to other authors [2,17-19], in oocytes of $\mathrm{III}^{\circ}$ stage of Hoplostethus mediterraneus there were several layers of follicular cells and a pellucid zone with evident streaking. The yolk globules, found in Coelorhinchus appeared from the beginning of the 

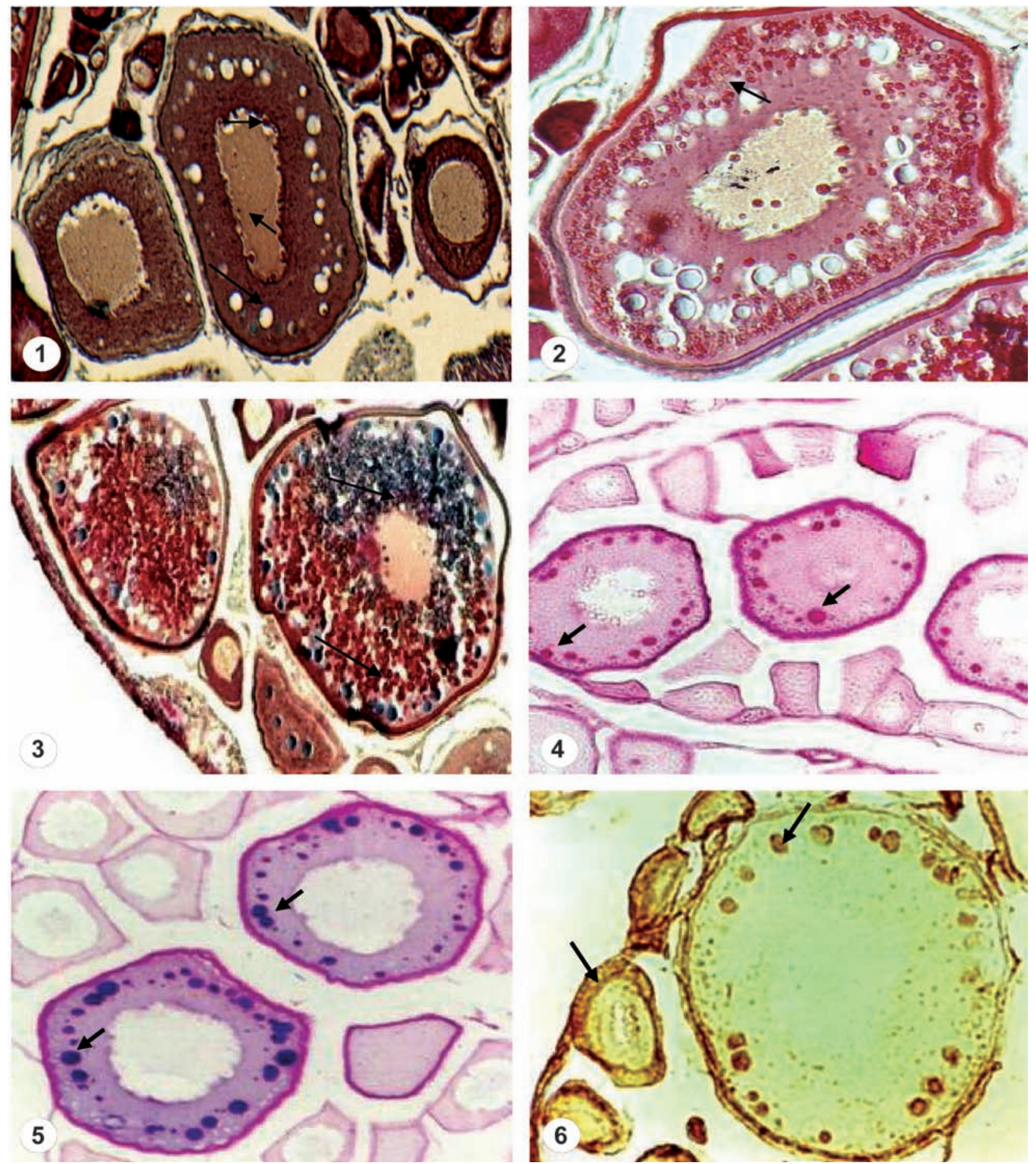

Fig. 1. Cross section of ovary. Oocytes in the different stages of the growth. Note follicular cells, vacuoles, peripheral nucleoli (arrows). Mallory's triple stain (magnification $\times 750$ ). Fig. 2. Vitellogenic oocytes. Note the yolk globules red stained (arrow). Mallory's triple stain (magnification $\times 750$ ). Fig. 3. Previtellogenic and vitellogenic oocytes. Note yolk globules blue stained (arrows). Galgano I stain (magnification $\times 900$ ). Fig. 4. Oocytes in different states of the growth. Note PAS positivity of the follicular cells and of the vacuoles (arrows). PAS sec. Mc Manus reaction (magnification $\times 750$ ). Fig. 5. Oocytes of the $\mathrm{I}^{\circ}$ and the $\mathrm{II}^{\circ}$ stages of the growth. The blue- purple stain in the vacuoles shows the coexistence of the glycoproteins and acid proteoglycans with -COOH groups (arrows). $\mathrm{AB} \mathrm{pH}=2.5$ - PAS (magnification $\times 750$ ). Fig. 6. Oocytes in the $\mathrm{II}^{\circ}$ stage. Note the follicular cells and vacuoles positive to RCA lectin (arrows) (magnification $\times 900)$.

third stage of growth preceded by vacuologenesis. The contents of the vacuoles, were at first without contents, and later basophilic for the presence of proteins and acid proteoglycans with -SH and - $\mathrm{COOH}$ groups. The yolk globules, first red stained by Mallory's method, during the vitellogenesis, changed stain from red to 

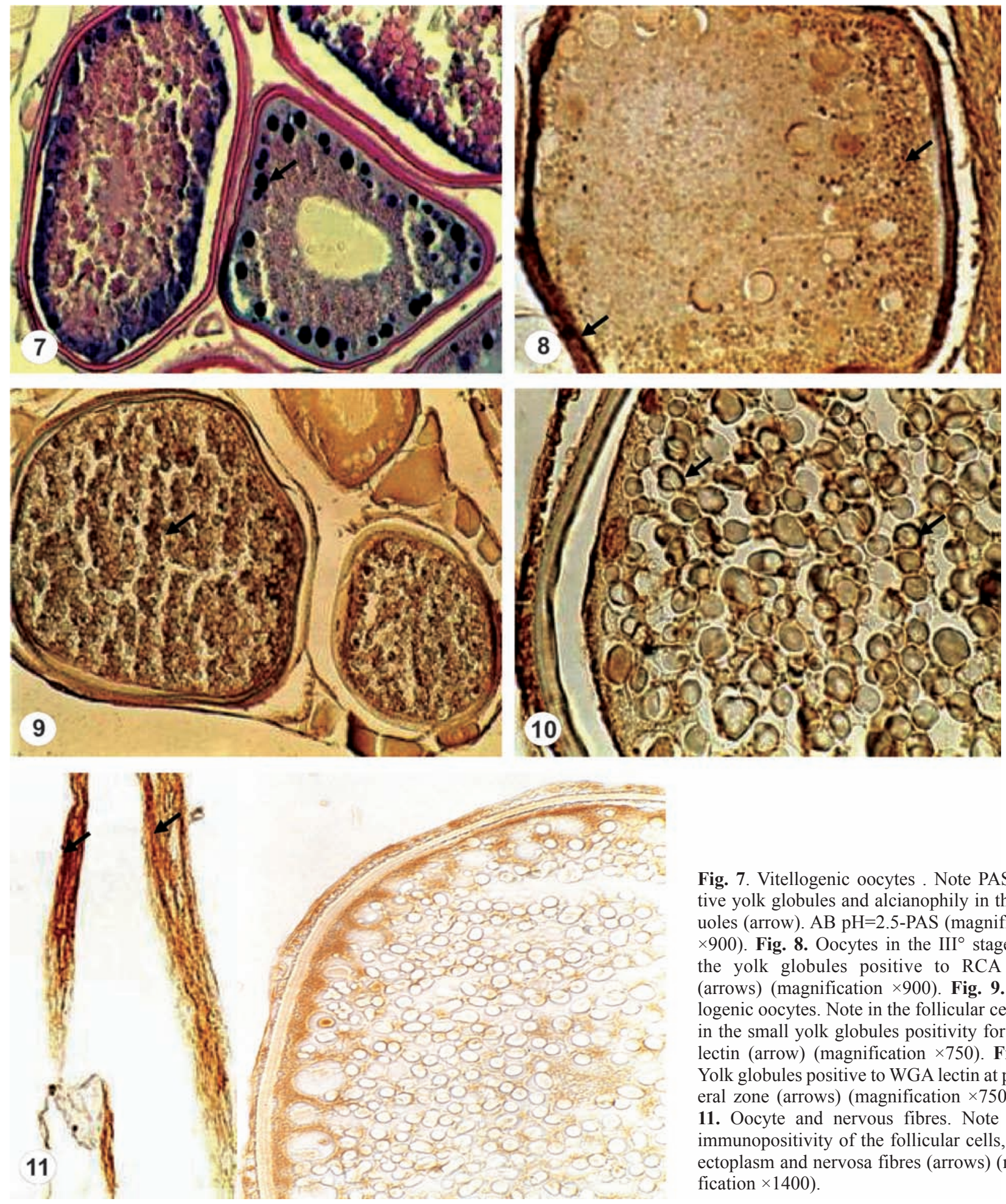

Fig. 7. Vitellogenic oocytes . Note PAS positive yolk globules and alcianophily in the vacuoles (arrow). $\mathrm{AB} \mathrm{pH}=2.5$-PAS (magnification $\times 900$ ). Fig. 8. Oocytes in the III $^{\circ}$ stage, note the yolk globules positive to RCA lectin (arrows) (magnification $\times 900$ ). Fig. 9. Vitellogenic oocytes. Note in the follicular cells and in the small yolk globules positivity for ConA lectin (arrow) (magnification $\times 750$ ). Fig. 10 . Yolk globules positive to WGA lectin at peripheral zone (arrows) (magnification $\times 750$ ). Fig. 11. Oocyte and nervous fibres. Note nNOS immunopositivity of the follicular cells, of the ectoplasm and nervosa fibres (arrows) (magnification $\times 1400$ ).

blue, their chemical constitution remaining however unchanged.

The absence of the contents in the vacuoles from the beginning, was according to was found in Coelorhinchus coelorhynchus [19] and in Channa [20], but not according to Mictophum punctatum [3], an abyssal species, in whose oocytes, the vacuoles had a basophilic contents constituted by glycoproteins, that is by the same substances found in the yolk globules from the beginning of the vitellogenesis. These results confirmed what supposed for Coelorhinchus, and Channa, i.e. it was a delayed condensation.

Nucleolar apparatus in oocytes of $\mathrm{IV}^{\circ}$ stage showed small variations in chemical constitution and in stain- 
ing affinities; no correspondence with staining variations of yolk globules. Therefore Hoplostethus mediterraneus was different from abyssal species Coelorhinchus coelorhynchus, [21] and from pelagic species Coris julis [22] and Gobius cobitis [2], in fact in the nucleoli of these species there occurred a coincidence between variations in staining affinities and chemical constitution.

The presence of follicular epithelium structurally different in the different stages of growth and the invariability of chemical constitution of yolk globules permitted to state that also in this examined species, the substances responsible to constitute yolk globules are exogenous, probably synthesized in liver [22-24], carried by blood to the follicular epithelium and at last in the oocyte.

The positivity revealed after use of all lectins is different by Coelorhinchus, in which the follicular cells were positive for some lectins only.

Similar results in Hoplostethus and in Coelorhinchus with regard to positivity for the WGA and SBA were found both in the yolk globules and in the periphery of globules at the end vitellogenesis. The hypothesis was that in Hoplostethus other groups in the molecular structure might mask the inreactivity of specific sugar radicals for all lectins used.

VIP and nNOS immunoreactivity elevated at the periphery of the cytoplasm of the oocytes and in the follicular cells, and the evidence of network of nerve fibres between oocytes during vitellogenesis, as found in other species $[8,10]$ suggested that the presence of $\mathrm{NO}$ and its synergism with VIP is a challenging subject to study due to wide variety of biological actions of NO and VIP on regulation of gametogenesis and spawning of both invertebrates and vertebrates.

\section{References}

[1] Albanese-Carmignani MP. Le trasformazioni del vitello proteico negli ovociti degli Invertebrati e dei Vertebrati. Atti Acc Pelor Pericolanti, Sc Fis Mat Nat. 1980;55:19-28.

[2] Albanese MP, Calabro C, Fasulo S, Minniti F. Aspetti morfologici e citochimici dell'apparato nucleolare e dei globuli di vitello negli ovociti in accrescimento del Teleosteo Gobius cobitis Pallas. Riv Biol Norm Patol. 1982;8:15-37.

[3] Bonina MT, Contini A. Osservazioni annuali sulle variazioni citochimiche degli ovociti in accrescimento del Teleosteo Mictophum punctatum. Raf Mem Bio Mar Ocean. 1974:2342.

[ 4] Nosek J, Krajhanzi A, Kocourek J. Studies on lectins. Immunofluorescence localization of lectins present in fish ovaries. Histochemistry. 1983;57.

[ 5] Krajhanzi A, Nosek J, Habrova V, Kocourek J. An immunofluorescence study on the occurrence of endogenous lectins in the differentiating oocytes of Silver carp (Hypophthalmichthys molitrix Valenenc.) and tench (Tinca tinca L) Histochem J. 1984a;16:432-434.

[6] Schindler LF, Devries U. Polarized distribution of binding sites for concanavalina A and weat - germ agglutinin in the zona pellucida of goodeidoocytes (Teleostei). Histochemistry. 1989;91:413-417.

[7] Contini A, Falugi C, Fasulo S, Mauceri A, Ricca MB, Zaccone G. Lectin binding sites in the growing oocytes Teleost fishes. Atti $53^{\circ} \mathrm{C}$ UZI. 1990;202-203.

[ 8] Annikova LV, Dyuizen IV, Paltseva YN, Varaksin AA. Putative nitric oxide synthase containing nervous elements in male and female gonads of some marine bivalve mollusks revealed by NADPH-diaphorase histochemistry. Invertebr Reproduct Developm. 2001;40:69-77.

[ 9] Licata A, Ainis L, Martella S, Ricca MB, Licata P, Lauriano $\mathrm{ER}$, Zaccone G. Immunohistochemical localization of nNOS in the skin and nerve fibres of the earthworm Lumbricus terrestris L (Anellida Oligochaeta). Acta Histochem. 2002;104: 289-295.

[10] Licata A, Ainis L, Martella S, Ricca MB, Licata P, Pergolizzi $\mathrm{S}$, Calabro $\mathrm{C}$, Zaccone G. Immunohistochemical localization of nNOS and VIP in the mantle integument of the mussel Mytilus galloprovincialis. Acta Histochem. 2003;105:143149.

[11] Curry WJ, Fairweather I, Johnston CF, Halton DW, Buchanam KD. Immunocytochemical demonstration of Vertebrate neuropeptides in the earthworm Lumbricus terrestris L. Cell Tissue Res. 1989;257:577-586.

[12] Elphick MR, Green IC, O'Shea M. Nitric oxide synthase and action in an invertebrate brain. Brain Res. 1993;619:344-346.

[13] Martinez A, Riveros-Moreno V, Polak JM, Moncada S, Sesma P. Nitric oxide (NO) synthase immunoreactivity in the starfish Marthasterias gracilis. Cell Tissue Res. 1994;275:599-603.

[14] Pearse AGE. Trattato di Istochimica I Piccin. Ed. Padova. 1989.

[15] Arndt EA. Histologische und histochemische untersuchungen uber die oogenese Und bipolare differenzierung von Susswasser Teleostern. Protoplasma. 1956;47:1-36.

[16] Wegmann I, Gotting K. Untersuchungen zur Dotterbildung in den Oocyten von Xiphophorus helleri (Heckel, 1948) (Teleostei Poeciliidae) Z Zellforsch. 1971;119:405- 433.

[17] Guraya SS. The Cell and Molecular Biology of Fish Oogenesis. ICMR Regional Advanced Res Center in Reproductive Biology. Kanger Basel New Delhi, 1986:1-223.

[18] Laale HW. The previtelline space and egg envelopes of bony fishes: a review. Copeia. 1980:210-226.

[19] Hsu SM, Raine L. Versatility of biotin-labeled lectins and avidin-biotin peroxidase complex for localization of carbohydrate in tissue sections. J Histochem Cytochem. 1982;30:157161.

[20] Guraya SS. A comparative histochemical study of Fish (Channa mariulus) and amphibian (Bufo stomaticus) oogenesis. $Z$ Zellforsch. 1965;65:662-700.

[21] Calabro C, Albanese MP. Istochimica dei glicosaminoglicani negli ovociti del Teleosteo abissale Coelorhinchus coelorhynchus (Risso). Riv Idrobiol. 2001;40:368-378.

[22] Albanese-Carmignani MP. Comportamento dell'apparato nucleolare in relazione a quello dei globuli vitellini negli ovociti in accrescimento del Teleosteo Coris julis L. Arch Zool Ital. 1970;55:87-96.

[23] Zahnd JP, Clavert J. Etude comparative des modification hepatiques liees a la vitellogenčse chez quelques Poissons CR. Soc Biol. 1960;154:1317-1319.

[24] Krajhanzi A, Nosek J, Monsigny M, Kocourek J. Direct visualization of endogenous lectins in fish oocytes by glicosylated fluorescent cytochemical markers. Histochem J. 1984b;16: 426-428.

Submitted : 10 January, 2007 Accepted after reviews: 30 December, 2007 